\title{
PENGARUH ATTACHMENT TERHADAP ORIENTASI PERILAKU PROSOSIAL PADA REMAJA DI SEKOLAH MENENGAH ATAS NEGERI (SMAN) 2 BEKASI
}

\author{
Eva Wulandari \\ Psikologi, Fakultas Ilmu Pendidikan, Universias Negeri Jakarta \\ Jl. Rawamangun Muka, Jakarta
}

Email: eva.wulandari15@gmail.com

\begin{abstract}
This research is aimed to analyze the effect of attachment on orientation prosocial behavior of Adolescents. The research was conducted at 2 State High School of Bekasi. The method used in this study is quantitative research methods using the Ex Post Facto design. The sampling technique in this study is proportionate stratified probability sampling with random sampling. The number of samples used in this study as many as 100 people. Data analysis techniques are used to test the hypothesis is to test the regression by using SPSS 20. Based on the results of a calculation, a large effect (Adjusted R Square) variable attachment to orientation of prosocial behavior were $0.123(12.3 \%)$, which means that attachment affects orientation of prosocial behavior as much as $12.3 \%$ and the remaining $87.7 \%$ is influenced by factors other than attachment. The results showed Ha received so it can be concluded that there is influence of attachment on orientation of prosocial behavior in adolescents in State High School (SMAN) 2 Bekasi.
\end{abstract}

\section{Keywords: Attachment, Orientation, Prosocial Behavior, Adolescents}

\section{PENDAHULUAN}

Masa remaja merupakan suatu fase peningkatan kebutuhan pada perilaku prososial. Usia remaja diharapkan mampu mengembangkan pribadinya sesuai nilai etika dan moral dengan berorientasi perilaku prososial, namun remaja di Indonesia saat ini sedang mengalami perubahan sosial yang cepat dari masyarakat tradisional menuju masyarakat modern, yang juga mengubah norma-norma, nilai-nilai dan gaya hidup mereka. Remaja yang dahulu terjaga secara kuat oleh sistem keluarga, adat budaya serta nilai-nilai tradisional yang ada, telah mengalami pengikisan yang disebabkan oleh urbanisasi dan industrialisasi yang cepat. Sesuai dengan pendapat Papilaya yang mengemukakan bahwa manusia Indonesia ditengarai mulai menunjukkan ciri-ciri dan karakteristik kepribadian yang individualis, materialis dan hedonistik (Asia, 2008).

Seiring dengan kemajuan teknologi informasi pada masa sekarang, nilai-nilai perilaku prososial di dalam kehidupan sehari-hari khususnya di Indonesia menunjukkan perkembangan yang cukup menarik, menyebabkan sikap individu menjadi semakin individualis dan sikap sosial yang dimiliki individu semakin pudar. Hal ini diperkuat oleh pendapat Fida (Isnandar, 2010) yang menjelaskan bahwa gerakan modernisasi yang meliputi segenap aspek kehidupan manusia menimbulkan terjadinya pergeseran pada pola interaksi antarindividu dan berubahnya nilai-nilai dalam kehidupan bermasyarakat. Interaksi antarindividu menjadi bertambah longgar dan kontak sosial yang terjadi semakin rendah kualitas dan kuantitasnya. Kemajuan alat komunikasi menyebabkan munculnya alat-alat komunikasi yang memungkinkan manusia berkomunikasi dari jarak jauh secara langsung, sehingga berdampak berkurangnya budaya silaturahmi antarindividu.

Sebagai makhluk sosial, manusia khususnya remaja diharapkan memiliki orientasi perilaku prososial yang tinggi, karena dalam perilaku prososial bertujuan untuk mensejahterakan orang lain dan mengurangi penderitaan bila dalam kesulitan. Perilaku prososial yang dilakukan diharapkan akan menciptakan kehidupan yang lebih selaras, terbentuk perilaku saling tolong menolong, menghargai, dan terjalin hubungan yang harmonis antara individu satu dengan individu yang lain. 
Fenomena yang terjadi di SMAN 2 Bekasi cukup menjelaskan bahwa tidak semua remaja yang tinggal di kota berorientasi perilaku antisosial, masih ada sekumpulan remaja yang peduli dan memiliki jiwa sosial yang cukup tinggi. SMAN 2 Bekasi termasuk salah satu sekolah negeri unggulan di kota Bekasi. Banyak siswa yang menjadikan SMAN 2 Bekasi sekolah favorit dan ingin menjadi siswa atau bagian dari sekolah tersebut. Tidak sedikit pula siswa yang tidak lolos seleksi masuk SMAN 2 Bekasi kemudian masuk ke sekolah swasta selama 1 tahun lalu pindah ke SMAN 2 Bekasi. Selain letak sekolah yang strategis, gedung yang cukup bagus, lingkungan sekolah yang asri dan nyaman, pendidikan di sanapun terkenal bagus. Tidak heran banyak siswa maupun orang tua yang menginginkan anaknya bersekolah di sana.

Secara umum perilaku prososial merupakan suatu tindakan menolong yang menguntungkan orang lain tanpa harus menyediakan suatu keuntungan langsung pada orang yang melakukan tindakan tersebut, dan mungkin bahkan melibatkan suatu resiko bagi orang yang menolong (Baron \& Byme, 2005). Bentuk-bentuk perilaku prososial ini seperti menolong, bekerjasama, jujur, berderma dengan melayani kebutuhan orang lain. Perilaku prososial ini muncul atas inisiatif sendiri, termasuk juga bentuk pertolongan apa yang akan digunakan individu dalam memberikan bantuan pada orang lain.

Orientasi perilaku prososial pada remaja, umumnya muncul dengan melakukan peniruan terhadap lingkungannya, seperti orang tua, teman atau guru. Jika ia mampu berperilaku menyenangkan orang lain, maka ia akan mendapatkan reward dalam bentuk pujian dan penerimaan sosial dari lingkungan terhadap dirinya (Asia, 2008).

Sesuai dengan pandangan teori belajar, respon-respon prososial timbul karena adanya reinforcement (pengukuh). Penelitian yang dilakukan oleh Moss dan Page (Baron \& Byrne, 2005) menyatakan bahwa seseorang yang mendapatkan pengukuh positif pada saat melakukan suatu perilaku prososial maka ia cenderung akan melakukan perilaku itu lagi pada saat yang lain, sedangkan seseorang yang mendapatkan pengukuh negatif pada saat melakukan suatu perilaku prososial maka akan cenderung menghindari perilaku tersebut pada saat yang lain.

Memang banyak faktor yang melatarbelakangi seseorang dalam memiliki orientasi perilaku prososial, seperti yang telah disebutkan di atas, namun hubungan yang terjalin dengan orang tua adalah faktor penentu utama dalam keberhasilan dalam berperilaku prososial ketika berinteraksi di lingkungan sosial yang lebih luas. Bahkan kecerdasan-kecerdasan itu akan muncul dengan baik jika hubungan mereka berjalan juga dengan baik. Orang tua yang berada dalam suatu keluarga memiliki peran penting dalam pembentukkan dan arahan perilaku remaja.

Hal-hal yang diperoleh dari lingkungan keluarga terlebih orang tua akan menentukan cara-cara remaja dalam melakukan interaksi dengan lingkungan sosial di luar keluarga, dan akan digunakan sebagai dasar untuk menjalani kehidupan sosial yang lebih kompleks. Interaksi diantara orang tua dan anak yang tidak lancar akan mengakibatkan pada interaksi remaja di luar keluarga juga mengalami hambatan. Hetherington dan Parke (1999) mengatakan bahwa sebagaimana perilaku prososial pada umumnya, perkembangan perilaku prososial dipengaruhi banyak faktor. Salah satunya adalah faktor keluarga (Tambunan \& Retnaningsih, 2007).

Dalam keluarga adanya hubungan afeksi antara orang tua dan anak. Hubungan afeksi yang mendalam tersebut sering disebut attachment. Teori attachment yang diformulasikan oleh John Bowlby adalah teori yang paling berpengaruh pada zaman sekarang ini dalam membahas hubungan antara orang tua dengan anak maupun hubungan dekat lainnya. Attachment adalah ikatan afeksi yang dibentuk antara satu individu dengan yang lainnya dan bertahan sepanjang waktu dan tempat (Ainsworth; Ainsworth dan Bell; Bretherton, dalam Zanden, 1997, dalam Tambunan \& Retnaningsih, 2007). Bowlby (1979) dan Ainsworth (1989) juga mendefinisikan attachment sebagai ikatan afeksi antara individu (Edwards, 2002).

Attachment pada manusia pertama kali terbentuk dari hubungan antara pengasuh. Pada usia yang sangat dini, ikatan ini adalah antara bayi dan orang tua atau pengasuhnya. Banyak ahli psikologi yang menekankan pentingnya hubungan antara anak dengan pengasuh menjadi faktor penentu utama dalam keberhasilan anak berorientasi perilaku prososial ketika berinteraksi di lingkungan sosial yang lebih luas.

Secara umum attachment dibedakan menjadi secure dan insecure attachment. Insecure attachment kemudian masih dibedakan lagi menjadi tiga, yaitu insecure-avoidant attachment, insecure-resistance attachment, dan insecuredisorganized attachment (Ainsworth, dalam Hetherington dan Parke (1999), dalam Tambunan \& Retnaningsih, 2007). Perbedaan ini dapat diamati dari bentuk interaksi yang berlangsung antara anak dan pengasuhnya. Secure attachment diasosiasikan dengan cara pengasuhan orang tua yang sensitif dan konsisten (Cassidy \& Berlin, 
dalam Hetherington dan Parke (1999), dalam Tambunan \& Retnaningsih, 2007), responsif, interaksi yang syncrony (Isabella dan Belsky; Isabella, Belsky, dan Von Eye; Kochanska, 2000, dalam Tambunan \& Retnaningsih, 2007). Sebaliknya, insecure-avoidant attachment banyak dikaitkan dengan cara pangasuhan yang overstimuli dan mengganggu (Cassidy dan Berlin, dalam Tambunan \& Retnaningsih, 2007). Sedangkan insecure-resistance attachment dihubungkan dengan pengalaman pengasuhan yang inkonsisten, kurang terlibat dan kurang responsif (Cassidy dan Berlin; Isabella dan Belsky, dalam Berk (2000), dalam Tambunan \& Retnaningsih, 2007). Untuk insecuredisorganized attachment sering dikaitkan dengan pengasuhan yang sangat tidak adequat, yaitu adanya penolakan dan kekerasan fisik dari pengasuh (Lyons-Ruth dan Block, dalam Berk (2000), dalam Tambunan \& Retnaningsih, 2007).

Namun dalam bukunya yang kontroversial "The Nurture Assumption" Judith Rich Harris (2009) menjelaskan bahwa orang tua kurang atau bahkan tidak memiliki kekuasaan untuk menentukan menjadi seperti apa anaknya kelak, bahkan dalam perkembangan sosial mereka. Menurutnya cara atau interaksi awal dan hubungan afeksi orang tua dengan anaknya yang akan menentukan perkembangan anaknya itu hanyalah mitos budaya semata. Gen dan kekuatan peer group lah yang akan membentuk kehidupan anak-anak untuk kedepannya.

Dalam bukunya, Harris menyampaikan bahwa tidak ada bedanya antara anak yang diberi kasih sayang ekstra dengan kasih sayang yang sewajarnya atau bahkan diabaikan. Masalah pengukuhan yang diberikan pada setiap perilaku anak pun menurutnya tidak berpengaruh. Semestinya seorang anak akan menjadi seperti hasil didikan yg diperolehnya semasa mereka muda,namun dalam teorinya menyatakan nyatanya dalam banyak hal dan kasus, hasil akhir seorang anak (saat mereka dewasa) tidaklah sepenuhnya mencerminkan hasil didikan semasa mudanya, terutama pendidikan yg diperolehnya di rumah. Selain itu, asumsi dalam pemeliharan selama ini yaitu anak-anak yg lebih sering dipeluk dan mendapat curahan kasih sayang cenderung untuk bertumbuh menjadi dewasa sebagai orang yang "menyenangkan". Sebaliknya, anak yg lebih sering dipukul dan didisiplinkan secara keras cenderung untuk menjadi orang yang "sulit" atau "bermasalah" dikemudian hari. Namun sekali lagi Harris percaya bahwa proses hubungan ortu dan anak adalah dua arah, bayi yg "menarik" secara fisik (lucu, cantik, menggemaskan, dsb) cenderung untuk mendapat lebih banyak perhatian dan tindakan kasih sayang dibanding bayi yg penampilannya "kurang menarik".

Selain Harris, Knafo dan Plomin (2006) juga menjelaskan adanya pengaruh gen dalam menentukan perilaku pada anak terutama perilaku prososial. Meskipun beberapa penelitian melaporkan bahwa tidak ada pengaruh genetik pada dimensi tertentu seperti pada orang tua (Deater, Deckard, dan Rowe, dalam Knafo dan Plomin, 2006). Namun dalam penelitiannya, Knafo dan Plomin menemukan adanya pengaruh gen dalam menentukan perilaku prososial anak.

Adanya perbedaan pendapat antara teori tersebut yang masih belum menemukan kepastiannya, apakah terdapat pengaruh yang signifikan atau tidak signifikan antar 2 variabel tersebut. Alasan lain yang menjadi landasan penelitian ini adalah karena anak atau khususnya remaja adalah tunas bangsa yang akan meneruskan nilai-nilai kemanusiaan atau kebudayaan bangsa yang ramah, dan saling tolong menolong, untuk itu anak memerlukan bimbingan, arahan dan didikan dari orang tua sejak dini, sebagai persiapan untuk menghadapi masa yang akan datang, dan keluarga adalah masyarakat terkecil yang paling inti, dari keluargalah anak mulai memperoleh nilai-nilai kemanusiaan sebelum berhadapan langsung dengan orang lain, oleh karena itu attachment dalam mendidik anak akan mempengaruhi keberhasilan anak dalam perkembangan sosialnya. Selain itu, penelitian-penelitian tentang attachment-orientasi perilaku prososial pada remaja di Indonesia masih terbatas.

\section{METODE PENELITIAN}

Sample

Sampel dalam penelitian ini adalah siswa SMAN 2 Bekasi sebanyak 100 orang. Berikut ini adalah rincian populasi yang dijadikan objek penelitian:

Tabel 1

Data Seluruh Siswa SMAN 2 Bekasi

\begin{tabular}{lll}
\hline No & Kelas & Jumlah \\
\hline 1 & X & 636 \\
\hline 2 & XI & 521 \\
\hline 3 & XII & 495 \\
\hline Jumlah Siswa & 1652 \\
\hline
\end{tabular}




\section{Instrumen}

\section{Skala Attachment}

Untuk mengukur attachment ibu-anak, digunakan skala attachment yang diukur dengan mengacu kepada aspek-aspek dari Bowlby dan Ainsworth. Aspek-aspeknya adalah ketersediaan ibu, sensitivitas ibu, dan responsivitas ibu. Dari 25 item, 23 item yang digunakan untuk analisis. Adapun skor untuk respon dari item favorable akan memiliki bobot nilai empat untuk respon sangat sesuai, tiga untuk respon sesuai, dua untuk respon tidak sesuai, dan satu untuk respon sangat tidak sesuai. Respon dari item unfavorable akan memiliki bobot nilai satu untuk respon sangat sesuai, dua untuk respon sesuai, tiga untuk respon tidak sesuai dan empat untuk respon sangat tidak sesuai. Koefisien reliabilitasnya .842 .

\section{Skala Orientasi Perilaku Prososial}

Untuk mengukur orientasi perilaku prososial, digunakan skala orientasi perilaku prososial dengan mengacu kepada aspek-aspek orientasi perilaku prososial Cheung, Ma, dan Shek dengan pemisahan antara aspek berbagi dan bekerjasama, dikarenakan perbedaan arti atau pengertian. Sehingga dalam penelitian ini aspekaspeknya adalah perilaku menolong, perilaku berbagi, perilaku bekerjasama, hubungan afeksi, dan perilaku patuh terhadap aturan. Dari 50 item, 43 item yang digunakan untuk analisis, dengan koefisisen reliabilitas .899 .

\section{HASIL DAN DISKUSI}

Analisis data dilakukan secara kuantitatif. Untuk mengetahui pengaruh attachment terhadap orientasi perilaku prososial pada remaja di SMAN 2 Bekasi digunakan perhitungan dengan analisis regresi sederhana.

Tabel 2

Perhitungan Hasil Regresi

\begin{tabular}{llllll}
\hline Variabel & Konstanta & $\begin{array}{l}\text { Koefisien } \\
\text { Regresi }\end{array}$ & $\begin{array}{l}\text { Sig. } \\
\text { (p) }\end{array}$ & t & Sig. \\
\hline $\begin{array}{l}\text { Attachment } \\
\text { terhadap } \\
\text { orientasi } \\
\text { perilaku } \\
\text { prososial }\end{array}$ & 100.659 & .445 & .000 & 11,883 & .000 \\
\cline { 2 - 6 } & & & & & \\
\hline
\end{tabular}

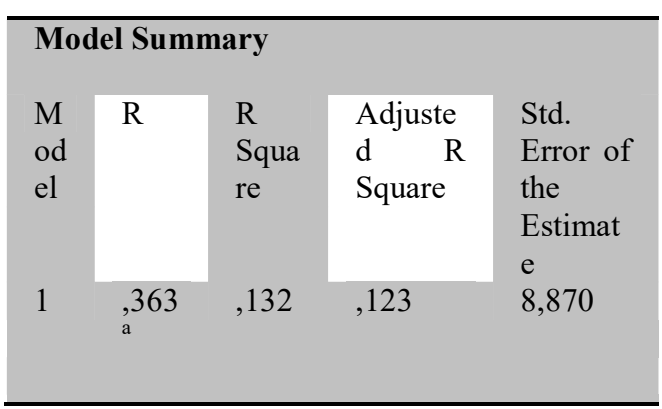

Dari hasil penghitungan data, telah dilakukan penghitungan dengan analisis regresi sederhana, dan dari hasil tersebut didapatkan bahwa terdapat pengaruh yang signifikan antara attachment terhadap orientasi perilaku prososial pada remaja. Hal ini diketahui dari harga $\mathrm{t}=3.799$ yang memiliki signifikansi 0.000 .

Berdasarkan perolehan tersebut dapat disimpulkan bahwa attachment memiliki pengaruh terhadap orientasi perilaku prososial pada remaja di SMAN 2 Bekasi. Besarnya sumbangan attachment terhadap orientasi perilaku prososial diketahui dengan melihat perolehan nilai Adjusted $R$ Square. Nilai $R$ Square yang diperoleh pada penelitian ini sebesar 0.123 atau sebersar $12.3 \%$. Hal ini menunjukkan bahwa sisanya sebesar $87.7 \%$ dipengaruhi oleh faktor lain selain attachment. Secara statistik nilai ini memberikan penjelasan bahwa orientasi perilaku prososial dipengaruhi oleh attachment.

Jika melihat penjelasan mengenai orientasi perilaku prososial, banyaknya beberapa faktor yang mendasari individu untuk berperilaku prososial diantaranya ada faktor situasi, salah satunya seperti adanya bystanders (orang lain yang kebetulan berada bersama kita di tempat kejadian) yang menurut Sarlito (2002) sebagai faktor utama. Adanya desakan waktu yang biasanya individu yang sibuk dan tergesa-gesa cenderung tidak menolong. Keterbatasan kemampuan yang dimiliki individu juga menjadi salah satu faktor lainnya, dimana individu yang merasa mampu, ia akan cenderung menolong. Selain faktor situasi ada pula faktor lain yaitu faktor pengaruh dari dalam diri. Dimana adanya perasaan yang sedang dirasakan oleh individu terkadang juga menjadi salah satu sebab ia akan menolong atau tidak, biasanya individu yang sedang merasakan perasaan yang positif cenderung akan menolong, begitu sebaliknya individu yang sedang merasakan perasaan negatif atau sampai dalam keadaan depresi cenderung tidak akan menolong orang lain.

Tidak hanya faktor-faktor yang telah dijelaskan di atas, kehidupan pertemanan pun ikut mempengaruhi bagaimana anak berperilaku. Kehidupan pertemanan membentuk hubungan 
yang erat antara individu dengan individu sebaya. Kehidupan pertemanan cenderung membawa pergaulan ke arah kelompok. Penerimaan untuk dapat terlibat dalam kegiatan kelompok bergantung pada sekumpulan sifat dan pola perilaku (Hurlock, 1980). Penerimaan terhadap keadaan individu dari teman maupun kelompok dapat memberikan pengaruh terhadap individu untuk mengikuti pola perilaku teman maupun kelompok tersebut. Individu yang sebelumnya berperilaku sesuai norma dapat menjadi individu yang berperilaku tidak sesuai norma. Individu yang lebih banyak menghabiskan waktunya bersama teman maupun kelompoknya, akan mempengaruhi kehidupan sosialnya terlebih dalam berperilaku. Walaupun tidak semua individu seperti itu, dikarenakan adanya kelekatan yang terjalin antara individu tersebut dengan keluarganya terlebih kepada ibu yang selalu memberikan perhatian dan kasih sayang, yang biasa disebut (attachment).

Attachment antara individu dengan ibunya dimulai dari individu tersebut lahir. Jika individu memiliki attachment yang secure terhadap ibunya, individu tersebut cenderung akan berperilaku prososial. Seperti yang dikemukakan oleh Retnaningsih \& Marliah (2007), "anak dengan secure attachment memiliki karakteristik cenderung akan lebih pintar dalam menyelesaikan masalah, lebih kooperatif, patuh pada orang tua, memiliki hubungan yang lebih baik dengan teman sebayanya, lebih mampu dalam mengambil inisiatif, dan memiliki empati terhadap orang lain". Begitu sebaliknya dengan individu yang tidak memiliki secure attachment, atau biasa disebut insecure attachment. Dimana mereka cenderung tidak berperilaku prososial, bahkan dalam kehidupan sosialnyapun memiliki masalah. Seperti yang dikemukakan oleh Retnaningsih \& Marliah (2007), "Kebalikan dari dampak secure attachment, anak insecure attachment memiliki ketergantungan berlebih pada orang tuanya, menjadi teman yang buruk, licik, dan manipulatif, serta mencari keuntungan dari kesulitan orang lain". Richters dan Waters (dalam Retnaningsih \& Marliah, 2007) berpendapat bahwa "Perbedaan individual dalam attachment menjadi penting karena implikasinya bagi perkembangan sosial anak selanjutnya".

Semakin individu memiliki secure attachment terhadap ibunya akan membuat perkembangan sosial individu tersebut baik dan memiliki kecenderungan untuk berperilaku prososial terhadap kejadian yang terjadi di sekitarnya.

Hasil dari penelitian ini dapat memberikan gambaran bagaimana orientasi perilaku prososial dan attachment, sehingga dapat dijadikan referensi untuk para ibu dalam menjalin kelekatan terhadap anak yang berdampak pada perilaku prososialnya. Jika permasalahan tidak ditangani dikhawatirkan membawa dampak negatif kedepannya pada diri anak.

\section{KESIMPULAN}

Berdasarkan hasil penelitian dapat disimpulkan bahwa adanya pengaruh yang signifikan attachment terhadap orientasi perilaku prososial pada remaja di Sekolah Menengah Atas Negeri (SMAN) 2 Bekasi.

Orientasi perilaku prososial pada remaja mempunyai pengaruh yang besar terhadap kelangsungan proses sosialisasi yang mereka jalani. Remaja akan lebih mudah untuk menyatu dengan lingkungan sekitar dan nyaman menjalani perkembangan sosial di lingkungan sekitar. Peran dari ibu diperlukan dalam upaya membentuk remaja agar memiliki perilaku prososial yang tinggi.

Walaupun demikian diketahui masih terdapat siswa yang memiliki orientasi perilaku prososial dan attachment yang tergolong kategori rendah. Adapun cara mengembangkan orientasi perilaku prososial dan attachment pada anak, salah satu caranya yaitu dengan menanamkan nilai-nilai perilaku prososial kepada siswa, seperti menolong orang lain, tidak memaksakan keinginan pribadi, serta belajar untuk berbagi dengan orang lain dan lebih menjalin kelekatan antara ibu dengan anak.

Perlu adanya konsistenan antara responsivitas dan sensitivitas ibu dari anak tersebut lahir dalam menciptakan kondisi dimana remaja merasa percaya dan nyaman ketika berada di lingkungan bersosialisasinya. Jika hal tersebut tercapai, maka remaja memiliki secure attachment, yang membangun karakteristik cenderung lebih pintar dalam menyelesaikan masalah, lebih kooperatif, patuh pada orang tua, memiliki hubungan yang lebih baik dengan teman sebayanya, lebih mampu dalam mengambil inisiatif, dan memiliki empati terhadap orang lain. Begitupun sebaliknya jika hal tersebut tidak tercapai, maka remaja memiliki insecure attachment, yang membangun karakteristik cenderung memiliki ketergantungan berlebih pada orang tuanya, menjadi teman yang buruk, licik, dan manipulatif, serta mencari keuntungan dari kesulitan orang lain.

Dengan begitu remaja yang memiliki secure attachment cenderung akan berorientasi perilaku prososial dalam lingkungan sosialnya, dan begitu juga sebaliknya dengan remaja yang memiliki insecure attachment, mereka cenderung 
tidak berorientasi perilaku prososial, bahkan dalam kehidupan sosialnyapun memiliki masalah. Adapun keterbatasan dan kelemahan penelitian ini, yaitu jumlah item penelitian yang

\section{DAFTAR PUSTAKA}

Alhusin, Syahri. 2003. Aplikasi Statistik Praktis dengan SPSS.10. Yogyakarta: Graha Ilmu.

Anna Armeini Rangkuti dan Ratna Dyah Suryaratri, 2009. Statistika Inferensial Untuk Penelitian Psikologi dan Pendidikan (Jakarta: Fakultas Ilmu Pendidikan Universitas Negeri Jakarta.

Arikunto, Suharsimi. 2002. Prosedur Penelitian (7th ed), Yogyakarta: Pustaka Pelajar.

Baron, Robert A., \& Donn Byrne. 2005. Psikologi Sosial (Ratna Juwita, penerjemah) (10th ed). Jakarta: Erlangga.

Bee. H. 2005. Lifespan Development. New York: Pearson Education, Inc.

Caplin, JP. 2006. Kamus Lengkap Psikologi (Dr. Kartini Kartono, penerjemah) (Rev. ed.). Jakarta: PT. RajaGrafindo Persada.

Casthazahra. 2010. Aksi Pelajar Damai Palestina. $4 \quad$ Juli, 2012 http://casthazahra.blogdetik.com/2010/0 6/12/aksi-pelajar-damaipalestina/\#more-507.

Cheung, Chung P., Hing Keung Ma., Daniel T. L. Shek. 1998. Conceptions of Success: Their Correlates With Prososial Orientation and Behaviour in Chinese Adolescents. Journal of Adolescence. No 21. 31-42.

Davies, D. 1999. Child Development: A Practitioner Guide. New York: The Guilford Press.

Davies, D. 2004. Child Development: A Practitioner Guide. New York: The Guilford Press.

Desmita. 2006. Psikologi Perkembangan. Bandung: PT. Remaja Rusda Karya.

Doyle, A. B., Morreti, M. M. 2000. Attachment to Parents and Adjustment in Adolescence. cukup banyak dalam penelitian ini, dikhawatirkan terjadi masalah dalam pengisian karena siswa bosan sehingga pada kuesioner ada beberapa item yang terlewat untuk diisi.

http://www.hcsc.gc.ca/hppb/childhoodyouth.

Edwards, Martha E. 2002. Attachment, Mastery, and Interdependence: A Model of Parenting Processes.Family Process, 41, 3, 389-404.

E-psikologi. 2002. Problem Kelekatan Anak. 4 April, 2012. http://www.epsikologi.com/epsi/search.asp.

Guilford, Jean P. 1978. Fundamental Statistic in Psychology \& Education (6th ed.). Kayakusha: Mc Graw Hill.

Harris, Judith Rich. 2009. The Nurture Assumption. New York: Free Press.

Hastings, Paul D., Kenneth H. Rubin., Laura Derose. 2005. Link Among Gender, Inhibition, and Parental Socialization in The Development of Prosocial Behavior. Merri II. Palmer Quarterly, 51, 4, 467493.

Hetherington, E. M., Parke, R. D. 1988. Child Psychology: A contemporary Viewpoint. Edisi 5. Boston: Mc. Grow-Hill Collage.

Hurlock, Elizabeth B. 1980. Psikologi Perkembangan (Suatu Pendekatan Sepanjang Rentan Kehidupan) (Istiwidayanti \& Soedjarwo, penerjemah) (5th e.d.). Jakarta: Erlangga.

Isnandar, Tri Windha. 2010. Hubungan Antara Konsep Diri Dengan Perilaku Prososial Pada Siswa SMA 1 Purwodadi. Skripsi. Universitas Muhammadiyah Malang.

Kamus Bahas Indonesia Online. (n.d.). 18 Juli, 2012.

http://kamusbahasaindonesia.org/orientas

Kipdiah, Maryatul. 2012. Pengaruh Kecerdasan Emosional Terhadap Perilaku Prososial pada Siswa Boarding School Fathan 
Mubina Ciawi Bogor. Skripsi. Universitas Negeri Jakarta.

Knafo, Arif dan Robert Plomin. 2006. Parental Discipline and Affection and Children's Prosocial Behavior: Genetic and Environmental Links. Journal of Personality and Social Psychology, 90, 1, 147-164.

Luthfiani, Fia Silfa. 2008. Hubungan Antara Kualitas Attachment Dengan Ibu dan Motivasi Berprestasi pada Santri Pondok Pesantren Tingkat Pertama di KotaKabupaten Tasikmalaya. Skripsi. Universitas Indonesia.

Namakuddn. 2011. Kisah 2 Remaja Chechnya yang Berusaha Hentikan Aksi Teroris Kristen Breivik. 4 Juli, 2012. http://namakuddn.wordpress.com/2011/1 1/16/kisah-2-remaja-chechnya-yangberusaha-hentikan-aksi-teroris-kristenbreivik/.

Nancy, Eisenberg., (eds.), 2006, Handbook of Child Psychology, New Jersey: John Wiley \& Sons Inc, (29/02/2012).

Nazir,Moh. 1999. Metodologi Penelitian. Jakarta: Ghalia Indonesia.

Nur Asia. 2008. Hubungan Antara Harga Diri dan Asertivitas Dengan Perilaku Prososial Pada Remaja. Skripsi. Surakarta. Universitas Muhammadiyah Surakarta.

Santrock, John W. 2002. Life-Span Development (5th e.d.). Jakarta: Erlangga.

Santrock, John W. 2005. Psycholog (7th e.d.). Boston: McGraw-Hill.

Sarlito, Sarwono. 2002. Psikologi Sosial (3rd e.d.). Jakarta: Balai Pustaka.

Seputar Indonesia. 2011. Yue Yue Tidak Tertolong. $\quad 4 \quad$ Juli, 2012. http://www.seputar- indonesia.com/edisicetak/content/view/4 $37825 \%$.

Siregar, A. R. 2010. Pengaruh Attachment Style Terhadap Kualitas Persahabatan. Skripsi. Universitas Sumatera Utara.

SMA Batik. 2012. PMR SMA Batik 2Adakan Aksi Donor Darah. 4 Juli, 2012. http://smabatik2.com/component/content /article/86-pmr-sma-batik-2-adakan-aksidonor-darah.html?showall=1.

Staub, E. 1979. Positive Social Behavior and Morality: Socialization and Development. New York: Academic Press.

Sugiyono. 2009. Metode Penelitian Kuantitatif, Kualitatif, dan $R \quad \& \quad D$ (7th e.d.). Alfabeta.

Sulaiman, Samad. 2003. Pengasuhan Prososialitas Anak. Jurnal Edukasi, 4, 2.

Suryoputro, Antono., Nicholas J. Ford., Zahroh Shaluhiyah. 2006. Faktor-faktor yang mempengaruhi Perilaku Seksual Remaja di Jawa Tengah: Implikasinya Terhadap Kebijakan dan Layanan Kesehatan Seksual dan Reproduksi. Makara. Kesehatan, 10, 1.

Tambunan, Siti Marliah., \& Retnaningsih. 2007. Peranan Kualitas Attachment, Usia, dan Jender Pada Perilaku Prososial. Jurnal Penelitian Psikologi, 12, 1, 120-129.

Vaughan, Graham M., Michael A. Hogg. 2005. Social Psychological (4th e.d.). London: Pearson Education.

Vivanews. 2012. Bakti Sosial untuk Masyarakat Pesisir Jakarta. 4 Juli, 2012. http://ureport.vivanews.com/news/read/2 89843-bakti-sosial-untuk-masyarakatpesisir-jakarta.

Zaden, J. W. V. 1985. Human Development (3rd e.d.). New York: Alfred A. Knopf. 